\title{
CLIC 2021. The Third Cultural Linguistics International Conference
}

\author{
(Széchenyi István Egyetem, online konferencia, \\ 2021. június 16-18.)
}

Cseh Lilla Zsófia, Galac Ádám

E-mail:l.zsofia.cseh@gmail.com;E-mail:adam.galac@gmail.com

A Nemzetközi Kulturális Nyelvészeti Konferenciát (Cultural Linguistics International Conference, CLIC) 2021-ben harmadik alkalommal rendezték meg, ezúttal Budapesten, június 16-18. között. Csak a színhely volt a tervek szerint Budapest, a szervezést a győri Széchenyi István Egyetem végezte. Első alkalommal az ausztráliai Monash Egyetem olaszországi, pratói oktató- és kutatóközpontja szervezte a konferenciát 2016-ban, másodszorra pedig a németországi Koblenz-Landau Egyetem 2018-ban.

Az első, pratói alkalmat az ausztráliai Monash Egyetem kulturális nyelvészeti tanszékvezetője és számos lényeges kötet, tanulmány szerzője, Farzad Sharifian indította útjára. A további két konferencia megtervezésében is aktív részt vállalt, de sajnos 2020 májusában váratlanul elhunyt. A 2021-es konferenciát ezért a szervezők az ő emlékének szentelték, 17-én az egyik panelbeszélgetésen Benczes Réka, Kövecses Zoltán, Zouheir Maalej, Marzieh Sadegh Pour és Ning Yu emlékeztek Sharifianra és munkásságára. Szintén az ő emlékére a három legjobbnak ítélt fiatal elöadó Sharifian egyik kötetét kapta jutalmul.

Az elsősorban Baranyiné Kóczy Judit által szervezett 2021-es konferencia a koronavírus-járvány miatt 2020-ról egy évet csúszott. Sajnos már június elején világossá vált, hogy a koronavírus-járvány harmadik hulláma okozta korlátozások miatt a legtöbb nem Budapesten tartózkodó előadó nem tud személyesen eljönni, így végül online, Zoomon sikerült a konferenciát lebonyolítani. Egyedül a vacsorát sikerült megszervezni, de a Kárpátia étterem helyett a szabadtéri Ezüstponty Vendéglöben került rá sor június 16-án este. Ezen körülbelül 20-25 fő tudott részt venni.

A CLIC 2021 konferencia központi témája, ahogy a címe is elárulja, a föleg az elmúlt évtizedben az érdeklődés középpontjába kerülő (inter-)kulturális nyelvészet

Hivatkozás: Cseh L. Zs., Galac Á. 2021. CLIC 2021. The Third Cultural Linguistics International Conference. CLIC (Széchenyi István Egyetem, online konferencia, 2021. június 16-18.) Fordítástudomány 23. évf. 2. szám. 123-124.

DOI: https://doi.org/10.35924/fordtud.23.2.9 
volt, szervesen kapcsolódva a modern kognitív nyelvészet azon alaptételéhez, hogy a nyelv kizárólag az őt létrehozó kontextusban vizsgálható és érthető meg. Ez a kontextus számos szinten és szempontból értelmezhető, ahogy azt a szekciók szükebb tematikáján is láthatjuk. Szó esett például - a gondolkodás és a nyelv testben gyökerező volta, az ún. embodiment összefüggésében - az egészség-betegség, a testrészek, az észlelés, valamint az érzelmek kulturális konceptualizációiról, illetve az ezek közötti különbségekröl. Hasonlóképpen univerzális tapasztalatokból ered, azonban kultúránként jelentősen eltérhet az egyes állatok megítélése és a hozzájuk kapcsolódó metaforikus kifejezések - ezzel a kérdéskörrel is egy külön szekció foglalkozott. További szekciók tárgyalták a különböző kulturális sémákat és konceptuális metaforákat, valamint ezek időbeli változását, oktathatóságát és lefordíthatóságát.

87 előadással csaknem 100 előadó és 50 érdeklődő jelentkezett be a konferenciára 28 országból és öt kontinensről. A megnyitót követő első plenáris előadást Kövecses Zoltán metaforakutató tartotta, aki innovatív módon a lehetö legkorábbra próbált visszatekinteni az időben, egészen az őskori emberek metaforikus gondolkodásának kezdetéig (pl. a tủz felfogása használati eszközként). A nagyszabású eseményen további négy plenáris előadó szerepelt: Barbara Lewandowska-Tomaszczyk (Konini Egyetem), Helen Meng (Hongkongi Egyetem), Hans-Georg Wolf (Potsdami Egyetem), végül pedig Pléh Csaba, a kognitív pszichológia professzora. Emellett két magas színvonalú tudományos kiadvány bemutatóját is hallhattuk: a Springer Singapore Publishing által jegyzett Cultural Linguistics könyvsorozatét, valamint a John Benjamins Publishing Company Cognitive Linguistic Studies címü folyóiratáét.

Idén az ELTE Fordítástudományi Doktori Programjából Cseh Lilla Zsófia tartott előadást a CLIC-en: a doktori dolgozatához végzett eddigi kutatásait foglalta össze Cultural issues and translation questions in translating manga címmel, ahol a japán képregények európai nyelvekre történő fordításait vizsgálta. Bemutatójában olasz, angol, francia, magyar és finn nyelvre történt fordításra is mutatott be példákat.

Kiemelendő még az ELTE Interkulturális Nyelvészet Doktori Iskolájának doktorandusza, Galac Ádám, aki a 2020/21-es ÚNKP-ösztöndíjas kutatásának eredményeiröl számolt be. Basic-level multimodal perception verbs in French, Spanish, and Hungarian: a contrastive study of sentir and érez címü elöadásával bekerült azon három PhD-hallgató közé, akik elnyerték a kulturális nyelvészet úttöröjéröl és a konferencia alapítójáról, Farzad Sharifianról elnevezett díjat, és ezzel együtt a Marzieh Sadeghpour és Farzad Sharifian által szerkesztett Cultural Linguistics and World Englishes címü, 2021-ben megjelent tanulmánykötet egy példányát. A kötet tanulmányai az angol nyelv különböző változatai mögött rejlő kulturális konceptualizációkat tárgyalják, elsősorban a klasszikus értelemben vett angol nyelvü kultúrákon túlmutatóan: az ausztrál öslakosság körében, Kelet-Ázsiában, Indiában, Szaúd-Arábiában, Afrikában, továbbá a szerb, német és brazil anyanyelvü közösségekben. 